Yu. V. Dubiei, Cand. Sc. (Econ.), orcid.org/0000-0003-3415-3470

Dnipro University of Technology, Dnipro, Ukraine, e-mail: yuliya.dubey@gmail.com

\title{
MANAGEMENT OF REPRODUCTION OF CURRENT ASSETS OF MACHINE-BUILDING ENTERPRISES OF UKRAINE
}

Purpose. To determine the specifics of managing reproduction of current assets of machine-building enterprises and to substantiate modern directions of increasing their efficiency.

Methodology. The author uses the following methods: canonical and discriminatory analysis - in developing a conceptual approach to managing the reproduction of current assets of a machine-building enterprise; grouping - while breaking down the production cost of the machine-building enterprise; general and specific ones - in identifying the specifics of the enterprises of the machine-building complex in comparison with other industrial enterprises, as well as in the development of scientific and practical provisions that determine the formation of the resource queue, provided that the income covers (does not cover) the production cost; ranking - when determining the priority of covering costs.

Findings. The specifics of formation and use of current assets of machine-building enterprises is revealed, and based on this, a conceptual approach to managing their reproduction is proposed. The essence of the resource queue method is analyzed, and suggestions on its adaptation to the specifics of heavy engineering enterprises are developed. The resource queue method is shown on the example of railcar manufacturing at Public JSC "Dniprovahonmash", and the algorithm of the priority of the reproduction of resources under different conditions of cost-revenue ratio from its sale is proposed.

Originality. The resource queue method is improved in the part of the selection of the procedure of minimization of expenses within the limits of relatively stable cost components having the highest ranks of the priority of its coverage.

Practical value. Scientific results can be used by machine-building enterprises for efficient management of current assets in conditions of financial and economic instability.

Keywords: current assets, management of the reproduction of current assets, operational cycle, resource queue, cost, revenue

Introduction. Ukrainian engineering is a multi-sectoral complex, which is of paramount importance for the development of the economy at the national level, as it provides the population with consumer durables, while other industries with means of production. In essence, it is at the expense of the production of machine-building enterprises that a significant part of the productive forces of the national economy is formed, and their technological and innovation potential in the creation of the final product is determined.

One of the leading components of the machine-building complex of Ukrainian economy is the heavy machinery industry, because it is here that machinery and equipment is manufactured for such important industries of the country as metallurgy, coal, chemical, oil and gas industry, transport. By allocating an active part of the fixed productive assets of the enterprises of these industries, heavy engineering, thus, lays the foundation for their development in the direction of scientific and technological progress and productivity growth. The exceptional importance of heavy machinery in the sectoral structure of the economy and its impact on the rate of economic growth in the country require constant attention to the factors ensuring its effective functioning.

One of these factors is the creation of conditions for the expanded reproduction of assets of machine-building enterprises. Compared to other branches of the machine-building complex, heavy engineering is characterized by high metal content of products, long-life production cycle and, as a rule, low turnover of circulating assets. Moreover, in recent years in Ukraine, under the influence of a combination of economic, political and institutional factors, there have been negative trends in the structure and sources of the formation of current assets of domestic heavy machinery enterprises, which, of course, affects the results of their activities. Therefore, it is relevant to economic science and business practices in Ukraine to study reproduction patterns of current assets of machinebuilding enterprises as a prerequisite of their effective development and an important component of nation-wide economic growth.

Literature review. Attempts at solving the problems of resource provision of the industrial complex of Ukraine, includ-

CC Dubiei Yu.V., 2019 ing machine building, have been made extensively in domestic scientific research. Thus, in particular, Velykyi Yu. V. and Netudykhata K. L., while analyzing the main tendencies of machine-building enterprises of Ukraine, focus mainly on the dynamics, structure and sources of formation of their current assets, as well as attempt to comprehensively evaluate the effectiveness of their use [1]. Problems of estimating the efficiency of using current assets of domestic enterprises are also raised in works by Lebedeva A. M. [2] and Vaschenko N.V. [3]. In turn, Donin Y. O. offers new theoretical approaches to their classification and outlines the application areas of their use, based on the generalization of modern scientific and methodological approaches to the specifics of the classification of current assets [4].

If we consider the achievements of Ukrainian scientists in this area, among the existing research, the most active in the domestic economic thought is the discussion of issues directly related to the management of current assets of enterprises. Thus, Lysonkova N.M. and Zakharchuk V. Yu. consider the main principles, methods and stages of such management [5]. The ways of increasing the efficiency of management of current assets of enterprises are thoroughly analyzed by Zianko V.V. and Filatova N. M. The authors consider the specific features of managing current assets of the enterprise, analyze the influence of internal and external factors on their level, identify management methods, propose measures for acceleration of the cash assets turnover rate [6]. Specifics of current capital management on the example of the machine-building enterprise are considered in the works by Dehtiar N.A., Deineka O. V. and Chernous T. M., in which the authors substantiate the necessity and importance of effective management of current assets in the conditions of financial instability, analyze the indicators of the composition, structure and efficiency of this process [7]. Filatova N. M. emphasizes that in order to form a reproductive mechanism of current assets, it is necessary to improve the accounting of costs in production, which will allow the manufacturers to carry out a process of simple reproduction of production resources at the expense of cost [8]. Omelchenko L. S. and Piskuliova I. V. point out the main strategies for managing current assets of industrial enterprises, as well as types of policies for the formation and use of such assets [9]. 
Despite the availability of research on this issue, we cannot talk about solving all existing problems in the management of current assets of enterprises of the machine-building complex. One of the important components of ensuring the sustainable development of such enterprises in Ukraine is the effective reproduction of their current assets in order to create the necessary conditions for the continuity of the production process, as well as its financial and economic efficiency. At the same time, the reproduction of current assets that are advanced in circulation funds and current assets of economic entities has its own specific features that affect all stages of the functioning of machine-building enterprises and, thus, determines the results of their activities. To take into account this nature of the reproduction process, especially in the conditions of unstable development of the Ukrainian economy, it is often necessary to make non-standard decisions in the process of managing current assets, which requires corresponding theoretical substantiation.

Purpose. The aim of the article is to determine the specifics of managing the reproduction of current assets of machinebuilding enterprises and to substantiate the modern directions of increasing the efficiency of their use.

Methods. The methodology and research methods are based on the fundamental provisions of modern economic theory concerning the regularities of the reproduction process, scientific works by domestic and foreign researchers studying economics of enterprise and management. The author of the current research uses the following methods: canonical and discriminatory analysis - in developing a conceptual approach to managing the reproduction of current assets of a machinebuilding enterprise; grouping - when breaking down production cost; general and special methods - in identifying the specifics of the enterprises of the machine-building complex, as well as in developing the scientific and practical provisions that determine the formation of the resource queue, provided that the income covers (does not cover) the cost of production; ranking - when establishing the priority of covering the costs.

Results. The reproduction of the assets of industrial enterprises is a rather complicated process, and especially in the context of crisis and post-crisis periods, when economic agents face a shortage of their own financial resources and have limited access to external sources of funding in those volumes that would ensure continuity and increase the efficiency of their activities. Previous research highlights a number of reasons that cause problems in the process of reproduction of assets of Ukrainian enterprises, namely: irrational structure of working capital, high levels of taxes and rates of bank loan, low level of availability of high-quality working capital, disparity of prices for domestic products in comparison with the import prices, as well as insufficient level of support from the state. Although the above factors are important in the problems of the reproduction of assets of Ukrainian industrial enterprises, one of the key deficiencies, however, is imperfect management.

Experience has shown that most of our enterprises do not have adequate market conditions for the system of planning the provision of production activity as the main elements of working capital, do not systematically take measures to improve the use of available working capital, do not apply alternative scenarios for finding new sources of formation and reproduction of working capital, do not improve management policy of working capital components systematically [10]. All of this creates additional problems for enterprises for their effective functioning and achievement of success. While there are not so many opportunities at the disposal of enterprises for influencing the macroeconomic conditions of the reproduction process, still there are lots of opportunities to improve the efficiency of management. Taking into account the fact that current assets are the most mobile element of all assets of the company and the most important component of ensuring the continuity of production cycle and maintaining the necessary level of liquidity and solvency of the enterprise, the application of scientifically grounded strategies for managing their level and dynamics opens up significant opportunities in achieving high end results of activities for each industrial enterprise.

Speaking about the management of current assets of machine-building enterprises, it should be borne in mind that the direct object of management is characterized by certain nature that requires special conceptual approaches in management. According to our deep conviction, such an approach should, firstly, be based on a comprehensive analysis of the current state of formation and use of current assets, as well as the sources of their formation, and secondly, contain certain methodical tools for managing their separate structural elements and, thirdly, promote effective implementation of the goals of enterprise development. Taking all the above into account, we propose a conceptual approach to the management of the reproduction of current assets of machine-building enterprises in the context of strategic development of the industry, which is presented in the form of a flowchart in Fig. 1.

The specifics of this approach is that it is based on the interconnection of strategic goals (strategic aspects of management concept), the formation of scientifically sound methodological approaches to their implementation and the expected results. The proposed approach contains a scientific component, which is a connecting element in shaping the company's strategy and opportunities for obtaining the results of the activity. This component, in its function, is responsible for the scientific substantiation of the strategic and tactical steps that the enterprise must take in managing the reproduction of current assets. Consequently, the direct management process must be preceded by the research stage, the results of which will form a set of methodological developments, which can improve the management of reproduction of current assets of the machine-building enterprise. As the main components of this stage, we propose the use of three interrelated areas of research, namely: generalization of the theory and practice of formation of current assets and determination of their optimal structure, assessment of the efficiency of the use of current assets in the economic activity of the enterprise, analysis of sources of reproduction of current assets of the enterprise, taking into account the specifics of the industry. The result of scientific research is the formation of specific methodological approaches which, if used systematically, will allow the leaders of enterprises to timely adjust financial strategies, in particular, in terms of management of current assets. In our opinion, implementation of such management measures at certain stages will, in our opinion, promote sustainable and profitable development of enterprises (including participation in state sectoral and targeted programs), increase in competitiveness of products, as well as introduction of innovative projects and reduction of material intensity of the production.

In this flowchart of the conceptual approach, the direction of the study "Analysis of the sources of reproduction of current assets of the enterprise taking into account the specifics of the industry" deserves particular attention, as a result of which a methodological approach is created that allows the coordination of the sources of reproduction of current assets with the directions of their rational placement, since in conditions of unstable financial situation and crisis of finished goods sales, machine-building enterprises quite often face situations of search for mechanisms of reimbursement of resources spent during economic activity. Indeed, in recent years, most machine-building enterprises in Ukraine have seen an increase in the duration of operational and financial cycles, which is due to the reduction in sales volumes in the context of the crisis. Among systemic problems are the dubious debts of machinebuilding enterprises for performed work, the presence of a significant proportion of receivables with a maturity of more than three months, etc. All this reduces the profitability of enterprises and even makes them unprofitable. Under such condi- 


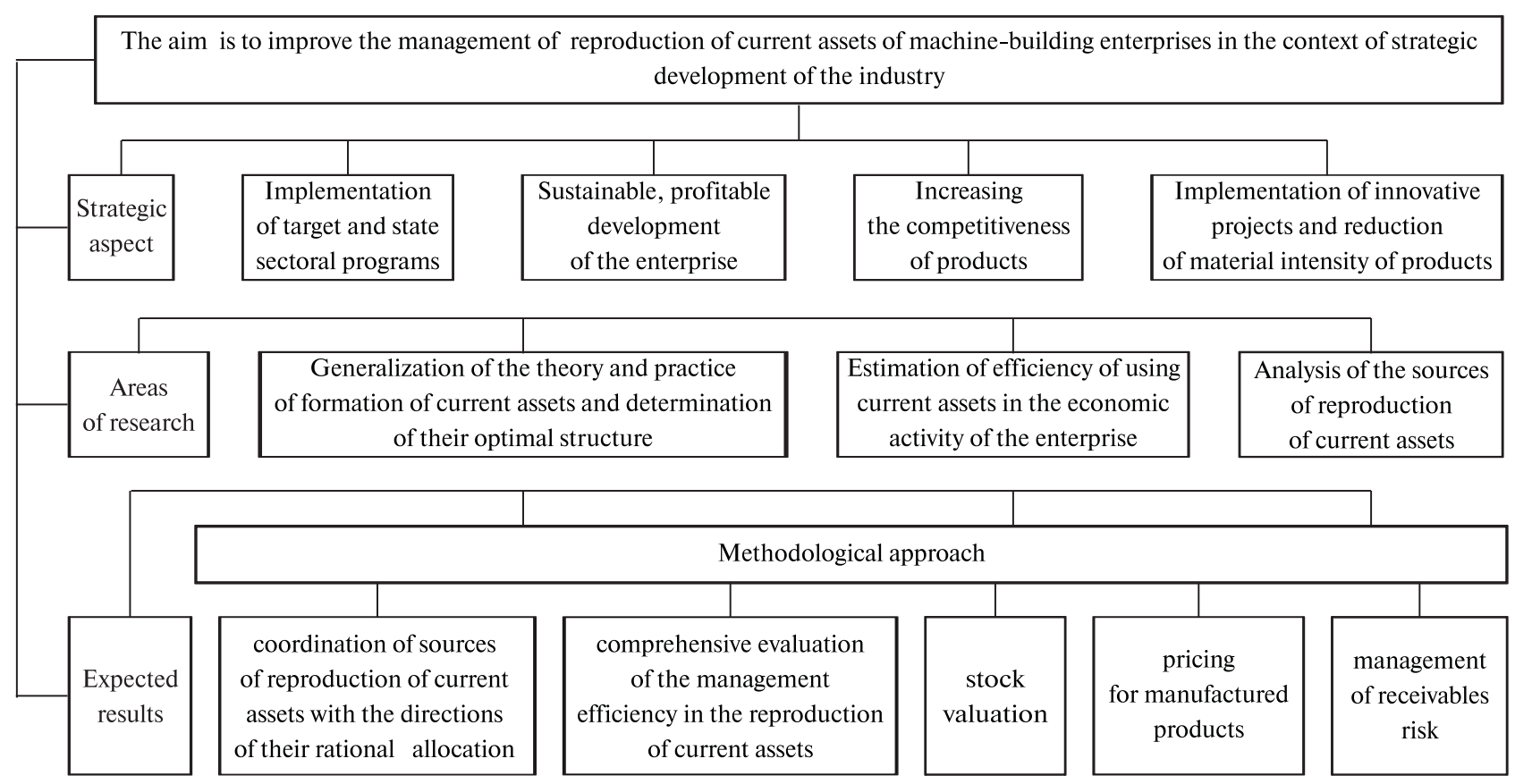

Fig. 1. Conceptual approach to managing the reproduction of current assets of the machine-building enterprise [11]

tions, the ability of enterprise executives to develop a strategy for leading enterprises out of a difficult situation becomes important.

As practice shows, in case of a loss-making activity of enterprises, their leaders always face a dilemma: which resources to compensate in the first place and which ones afterwards. In other words, we are talking about the technology of forming the so-called resource queue. This approach to managing the reproduction of current assets of an enterprise is based on a certain algorithm of the sequence of allocation of resources in various situations that arise because of market conditions fluctuations. The latter change the level of market prices and, therefore, lead to a growth or decrease in revenue depending on the situation. The methodical approach of the resource queue involves determining the priority of the compensation of production resources on the principles of assessing their importance for achieving the goals, firstly, to prevent suspension of production, and secondly, to minimize losses in cases where the return is less than the cost of production (for example [12]).

Despite the high predictive potential of this approach, its limitations should also be noted. First of all, it represents a slightly abstract management model that does not allow it to be applied in its pure form to the analysis of reality. Indeed, every branch of production has its own specifics, which affects the nature of reproductive processes. It is clear that the characteristics of the reproduction of assets in agriculture with its seasonality, the use of living organisms (animals, plants) and land resources as constituent production assets are not similar to enterprises, say, metallurgical complex or mining industry. For these reasons, the managerial approach to resource queues requires further elaboration in view of the need to develop adaptation mechanisms for its application to a specific production area.

In our opinion, the most significant specific features of the current assets of the machine-building enterprise and the sources of their reproduction in comparison with other industrial enterprises can be considered as:

- reduction of the proportion of receivables, inventories, cash and current financial investments at the expense of other components with the same ranking;

- prevalence of production stock and work in progress in the structure of current assets;

- the best liquidity positions;

- a larger share of equity capital and short-term bank loans in the structure of sources of reproduction of current assets;
- a greater proportion of profitable enterprises and higher return on business, which provides better conditions for expanded reproduction of current assets at the expense of profit;

- greater duration of the operating cycle and slower circulation of current assets.

Therefore, in order for the strategy of managing the reproduction of current assets to be effective, it must correspond to the specifics of the enterprises of the machine-building complex. As an example of the formation of a resource queue, let us consider the production of "A Type" railcars at PJSC "Dniprovahonmash". According to the resource queue method, at the first stage of the research it is necessary to structure the cost of production. This stage is the most important, because here it is possible to take into account the actual industry specifics of current assets. In the structure of the cost price of the "A Type" railcar, manufactured at PJSC "Dniprovahonmash", we have identified eleven types of costs, which reflect the cost involved in the production of resources (Table).

Special attention should be paid to the nature of machinebuilding enterprises and, especially, heavy engineering, which is high metal and material-intensive production. Moreover, the latter numerically prevails the former. Referring to the data in Table, it is obvious that the largest share in the structure of the cost of production of the "A" type railcar at PJSC "Dniprovahonmash" has semi-finished products and components (33.8\%), raw materials (33.3\%), as well as casting (6.2\%). Another feature of heavy machinery enterprises is the high labor-intensity of the products (the share of salary in the structure of expenses per one railcar is $9.3 \%$ ), which requires constant maintenance of the required level of employment. Taking into account the fact that machine-building enterprises, due to their specificity, cannot make a quick transition to new less costly technologies (even in the long run, such enterprises are characterized by increased inertia to innovations), then the only real means of keeping the company "afloat" in an unfavorable context is highly effective management.

To realize it in the sphere of influence on the reproduction of current assets of heavy engineering enterprises, when applying the resource queue method, it is necessary to distinguish, as an independent stage, the procedure for minimizing costs within the limits of three relatively stable components that occupy the highest ranks of the priority of their coverage. It means that the manager immediately rates the resources for raw materials, components and wages at high levels and works 
Table

Structure of the cost of production of an "A Type" railcar at PJSC "Dniprovahonmash" in 2017 [13]

\begin{tabular}{|c|l|c|c|}
\hline$\#$ & \multicolumn{1}{|c|}{ Cost } & $\begin{array}{c}\text { Amount, } \\
\text { UAH. }\end{array}$ & $\begin{array}{c}\text { Specific } \\
\text { weight, } \%\end{array}$ \\
\hline 1 & Depreciation of production equipment & 66000 & 3.3 \\
\hline 2 & $\begin{array}{l}\text { Depreciation of power machines and } \\
\text { installations }\end{array}$ & 42000 & 2.1 \\
\hline 3 & Salary & 186000 & 9.3 \\
\hline 4 & Charges for salaries & 42000 & 2.1 \\
\hline 5 & $\begin{array}{l}\text { Fuel (special and active coal, gasoline, } \\
\text { diesel fuel and oil refining products) }\end{array}$ & 42000 & 2.1 \\
\hline 6 & $\begin{array}{l}\text { Casting (steel, cast iron, nonferrous } \\
\text { casting) }\end{array}$ & 124000 & 6.2 \\
\hline 7 & $\begin{array}{l}\text { Spare parts (complex mechanics, } \\
\text { electrical equipment and electronics) }\end{array}$ & 44000 & 2.2 \\
\hline 8 & $\begin{array}{l}\text { Low-value and high-wear items (tools, } \\
\text { technical equipment, abrasives) }\end{array}$ & 42000 & 2.1 \\
\hline 9 & $\begin{array}{l}\text { Repair of production and power } \\
\text { equipment }\end{array}$ & 70000 & 3.5 \\
\hline 10 & $\begin{array}{l}\text { Raw materials (standard molded } \\
\text { products, pipeline fittings, rolled } \\
\text { metal, paint and varnish materials, } \\
\text { first coats and putty) }\end{array}$ & 666000 & 33.3 \\
\hline 11 & $\begin{array}{l}\text { Semi-finished products and } \\
\text { components }\end{array}$ & 676000 & 33.8 \\
\hline & Total & 1000000 \\
\hline
\end{tabular}

with their internal staff in order to minimize costs. Thus, it is not the order of attraction of some or other resources that is the subject of management, but work on already defined and relatively stable elements, since without the coverage of them the sense of holding the enterprise as a productive unit in general is lost. In relation to other expenses, management of the reproduction of current assets of a machine-building enterprise is realized according to the classic scenario. Thus, in the resource queue method, which is based on the assessment of the importance of timely implementation of costs in order to prevent the production from stopping and to minimize losses in cases where the revenue is less than the cost of production, a new component appears - cost minimization with relatively stable high-ranking elements of cost price.

We will demonstrate the prognostic possibilities of the resource queue method taking into account our proposals. We propose to consider as a benchmark situation a favorable situation, when the revenue from the sale of an "A Type" railcar is higher than the cost of their production. Under such conditions, the order of return of resources is not fundamental. The company's revenue in this case provides for the reimbursement of all production resources, and the company makes profit for its development. If the revenues are equal to expenses (in our example UAH 2000 thousand), then, respectively, there is a simple reproduction of resources.

In a situation where revenues do not cover production costs, the classic scenario of the implementation of the resource queue method raises the question as to which production resources should be restored in the first place, in order not to stop the process of their reproduction. From a theoretical point of view, there are many different combinations of options for reimbursement of spent resources, but practice shows that the ability of enterprise managers to adopt a particular management decision is rather rigidly determined by the existing factors of the internal and external environment in which business entities operate. The existing institutional conditions for conducting business, the existing technical and techno- logical features of production and sales of products, the situation of domestic and foreign markets of goods, etc. - all of these above affect the choice of enterprise management strategy and significantly limits the possible choice of options for the resource queue. According to our proposed modified version of the methodical approach of the resource queue, which takes into account the specifics of the operation of heavy engineering, the three elements of cost are given priority, namely: the cost of metal, materials and salary. In this regard, in our view, in conditions where the enterprise's revenue does not cover its costs, the compensation of production resources is possible in the combination, which is shown in Fig. 2.

As you can see, the fourth element of expenses is the first stage of ranking in income tax, which is important not only for the machine-building industry. This element is of first priority because today in the legal field of Ukraine there are rather rigid conditions of the tax legislation, the non-compliance entails a considerable amount of money in terms of penalties for late payment of taxes. This leads to the fact that there is no alternative to the primacy of this particular variant of the reimbursement of resources and leads to the fact that the taxes themselves take the first place in the considered resource queue. The tenth and eleventh elements lie a priori in the second and third stages of the order of reproduction, since they relate to those that determine the very technical and technological possibility of the functioning of the machine-building enterprise. This, as we pointed out earlier, is a specific feature of the industry and predetermines the concentration of management efforts in seeking to optimize the costs of raw materials, purchased semi-finished products and components.

The fourth step of the order of reconstruction is the third element of the cost price Table - salary. According to the economic realities of Ukraine, domestic enterprises often try to solve their questions of remaining in the relevant markets in crisis conditions at the expense of their employees. Despite the fact that under current conditions, the management of enterprises have not so many legal instruments of influence on the level of remuneration available (the requirements of the law on minimum wages, strict sanctions for the lack of official registration of employees, criminal liability for non-payment of wages, etc.), they find the necessary techniques of informal influence. From the practical point of view, this means that in the extreme situation, managers prefer the interests of production, hoping that the preserved technological and process-related components of enterprises will allow them to increase their activity in the post-crisis period. That is why, in Ukrainian realities, salaries of employees of an enterprise are some of the lowest places in the reproduction of current capital resources, which cannot be considered legitimate.

For heavy-industry enterprises, the issue of reducing wage bill costs is very important and is characterized by a certain duality. On the one hand, the company cannot guarantee that

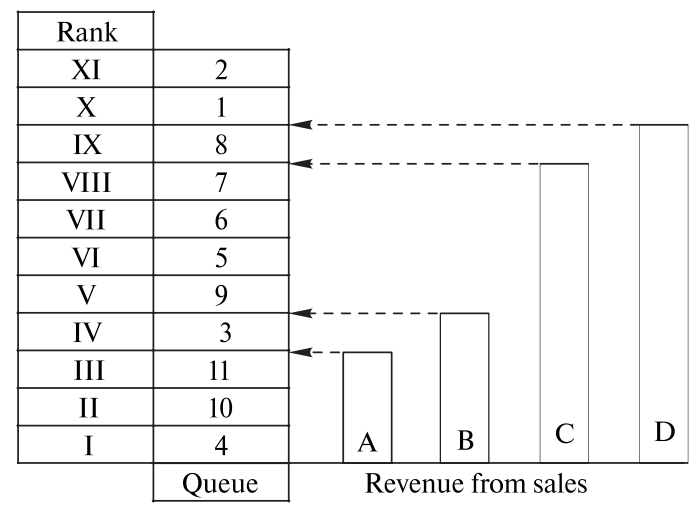

Fig. 2. Resource queue management, provided that the revenue does not cover production costs, where 1-11 are ordinal numbers of the items of expenditure indicated in Table 
lowering wages to the minimum will not provoke a high-skilled personnel outflow and will not create a technological barrier to maintenance of functionality. On the other hand, it should solve the problem of cost savings, operating in an industry with high labor intensity and high priority of reproduction of this cost component. In our opinion, the highest result of all existing restrictions in this area can be achieved through the development and implementation of non-standard approaches in personnel management. World experience suggests that taking into account the workers' behavioral characteristics that have formed in different countries and regions is a rather promising tool for influencing their attitude to the components of the production process, including the amount of remuneration.

So, the positive results of applying the methods of personnel management in American and Japanese companies are well-known. These methods are based on cross-cultural analysis, in particular methods for measuring cultural differences in the values by G. Hofstede (Hofstede, 1980, 1994, 2001), social energy by D. Earley (Earley, 1989) and H. Shirakashi (Shirakashi, 1985), the level of personnel turnover, depending on the organizational identification by F. Abrams (Abrams, 1998), and others. Yu. Pylypenko, H. Pylypenko, N. Lytvynenko and E. Prushkivska in their study $[14,15]$ obtain interesting results in the field of motivation for work, based on cross-cultural dimensions of mentality and socio-psychological orientations of the Ukrainian population.

In a national survey conducted by G. Hofstede and O. Potemkina, the researchers found that the average Ukrainians' orientation towards remuneration is slight as compared with Europeans, their predominant focus on their own process of work rather than on its outcome. The survey also established psychological inclination to a sense of importance of not just engagement in a certain business, namely work, as well as strongly expressed willingness to sacrifice oneself for the sake of the team, for social goals [16]. What distinguishes this study is its regional perspective. Taking into account the specifics of the concentration of heavy engineering enterprises in the regions of Ukraine, one can identify the specifics of the labor values of the population living there and being potential labor force for the enterprises of the corresponding profile. As it seems, the application of the results of cross-cultural analysis as a component of the resource queue method, implemented in the management of current assets of machine-building enterprises, is quite constructive, since it allows us to find acceptable limits of changing the amount of remuneration.

The next in the resource queue should be, in our opinion, the costs associated with the repair of machinery and fuel, foundry products, spare parts, low value items and wearable items. The lower ranking of the order of recovery of these elements of the cost of production of cars is due to the fact that they relate to those productive resources the absence of which will not stop the production process itself, but will lead to a decrease in the quality and quantity of manufactured products.

Finally, the lowest rank priority is the resources associated with depreciation deductions of capital productive assets. In other equal conditions, at least in the short term, absence of reproduction of these types of resources is not critical to the enterprise. Moreover, thanks to the depreciation fund, it can in some way solve its current problems if it ends up in the red. This is explained by the fact that the main productive assets are transformed into money in parts and gradually, which causes a long time lag of their transformation into its original form.

Thus, in our opinion, the order of compensation of production resources in the combination shown in Figure 2 is most effective in terms of the strategy of self-preservation of production. On the one hand, the resources that stand at the beginning of the queue provide adequate conditions for maintaining production, on the other hand, those that come at the end of the queue mitigate the consequences of negative financial results.
Taking into account the above said, there are following scenarios of management strategy of resource queues for different amounts of enterprise revenue from the sale of their products (positions of variants $A, B, C$ and $D$ in Fig. 2). Position $D$ describes a situation in which the revenue can cover the reproduction of all production resources, except for the depreciation of fixed assets. However, as already noted, the depreciation fund may be used by the company as a source of internal lending, including for covering losses from economic activity. In the case where the revenue from sales corresponds to position $C$, an enterprise minimizes its losses at the expense of those types of resources which will not stop production, if not renewed on a full scale; however, they can significantly degrade the quality and quantity of manufactured products. It is clear that such minimization has a certain lower limit, since less qualitative products at the same price will use less market demand. Finally, the position of the revenue from variants $B$ and $A$ allows expecting to cover only a part of the production resources in the critical group. From the theoretical and practical points of view, this situation, due to the devastating effects of social and technological factors, will result in suspension of production.

Conclusions. In the current conditions of financial and economic instability, the ability of enterprise managers to develop a well-considered strategy for managing resources, including current assets, is of utmost importance. Taking into account the specifics of reproduction of current assets in machine building, the conceptual approach to management in this field should be based on the organic interconnection of research, methodology and practice stages, the implementation of which will contribute to a more sustainable and efficient resource provision of business entities.

One of the managerial approaches to reproduction of current assets is the resource queue method, which, however, requires further elaboration in view of the need to develop adaptive mechanisms for its application in the field of heavy engineering. Taking into account the specifics of technological and economic processes in this sector, the resource queue method should include not only the determination of the priority of reproduction of productive resources in the context of a lossmaking activity, but also the procedure for minimizing costs within those relatively stable cost components that have the highest ranks of the priority of its coverage. From the standpoint of the strategy of self-preservation of production, this approach can both provide substantial conditions for the maintenance of production, and mitigate the negative consequences for the enterprise financial losses.

\section{References.}

1. Velykyi, Yu.V., \& Netudykhata, K. L. (2017). Analysis of the dynamics, structure and use of current assets of mechanical engineering enterprises. Naukovyy visnyk Khersonskoho derzhavnoho universytetu. Seriya Ekonomichni nauky, 23(3), 152-156.

2. Lebedieva, A. M. (2015). Methodological aspects of the analysis of the efficiency of the use of current assets of the enterprise. Zovnishnya torhivlya: ekonomika, finansy, pravo. Seriya. Ekonomichni nauky, 1(78), 67-76.

3. Vashchenko, N. V., \& Maximovich, Yu. I. (2013). Factors of formation and efficiency of use of potential of working capital of the enterprise. Innovatsiyna ekonomika, (6), 330-335.

4. Donin, Ye. O. (2018). Peculiarities of modern approaches to the specifics of the classification of current assets of enterprises. Ekonomika i orhanizatsiya upravlinnya, 1(29), 75-85.

5. Lysonkova, N. M., \& Zakharchuk, V. Yu. (2018). Increasing the efficiency of management of current assets of the enterprise. Pryazovskyy ekonomichnyy visnyk, 5(10), 354-357.

6. Zyanko, V. V., \& Filatova, N. M. (2012). Ways to improve the management of working capital of enterprises. Ekonomichnyy prostir, (62), 186-193.

7. Dekhtiar, N.A., Deineka, O. V., \& Chernous, T. M. (2017). Management of working assets of the enterprise. Ekonomika $i$ suspilstvo, 8, 572-578. 
8. Filatova, N. M. (2012). Peculiarities of management of current assets of the enterprise in modern economic conditions. In Rehionalna naukovo-tekhnichna konferentsiya profesorskovykladatskoho skladu, spivrobitnykiv ta studentiv universytetu, Vinnytsya. Retrieved from http//conf.vntu.edu.ua/allvntu/2012/inmen/txt/filatova.pdf.

9. Omelchenko, L. S. (2015). Analysis of Strategies for Managing Current Assets of Industrial Enterprises. Ekonomika: realiyi chasu, 3(190), 178-183.

10. Dubiei, Yu. V. (2018). Directions of effective management of working assets of industrial enterprises. Ekonomichnyi Visnyk Natsionalnoho Hirnychoho Universytetu, 1(61), 109-116.

11. Solyanyk, L. H., \& Dubiei, Yu. V. (2015). Working capital of machine-building enterprises: process of reproduction and optimization of structure. Momograph. Dnipropetrovsk, NHU.

12. Kurlykov, O. I. (2007). Method of resource queues and its application in solving the problem of replenishment of defense funds in market conditions. Ekonomicheskiy analiz: teoriya $i$ praktika, 3(84), 16-19.

13. Accounting reports of PJSC "Dniprovahonmash" for 2018. Retrieved from http://dvmash.biz/investor/8.doc.

14. Prushkivska, E. V., Pylypenko, H. M., \& Lytvynenko, N. I. (2013). Sociocultural Aspects of Economic Consciousness of Ukrainians. Ekonomichnyi Visnyk Natsionalnoho Hirnychoho Universytetu, 1(41), 34-45.

15. Pylypenko, H. M. (2013). Influence of Culture on the Relationship between State and Market Coordination in Ukraine. Naukovyi Visnyk Natsionalnoho Hirnychoho Universytetu, 3(135), 118-126.

16. Pylypenko, Yu., Pylypenko, H., Lytvynenko, N., Tryfonova, O. \& Prushkivska, E. (2019). Institutional components of socio-economic development, Naukovyi Visnyk Natsionalnoho Hirnychoho Universytetu, 3, 199-206. DOI: 10.29202/nvn$\mathrm{gu} / 2019-3 / 21$.

\section{Управління відтворенням оборотних активів машинобудівних підприємств України}

$$
\text { Ю. В. Дубєй }
$$

Національний технічний університет „Дніпровська політехніка“, м. Дніпро, Україна, e-mail: yuliya.dubey@ gmail.com

Мета. Визначення особливостей управління відтворенням оборотних активів машинобудівних підприємств і обгрунтування сучасних напрямів підвищення ефективності їх використання.

Методика. У роботі використані такі методи: канонічний і дискримінантний аналіз - при розробці концептуального підходу до управління відтворенням оборотних активів машинобудівного підприємства; групування - при виокремленні складових собівартості продукції машинобудівного підприємства; загального та особливого - при виявленні специфіки діяльності підприємств машинобудівного комплексу в порівнянні 3 іншими промисловими підприємствами, а також при розробці науково-практичних положень, що визначають формування ресурсної черги, за умови, що дохід покриває (не покриває) собівартість продукції; ранжування при встановленні пріоритетності покриття витрат.

Результати. Виявлена специфіка формування й використання оборотних активів машинобудівних підприємств і на цій основі запропоновано концептуальний підхід до управління їх відтворенням. Проаналізована сутність методу ресурсної черги й розроблені пропозиції щодо його адаптації до специфіки діяльності підприємств важкого машинобудування. На прикладі виробництва вагонів на ПАТ „Дніпровагонмаш“ застосовано методичний підхід ресурсної черги й запропоновано алгоритм черговості відшкодування ресурсів за різних умов співвідношення собівартості продукції та виручки від іï реалізації.

Наукова новизна. Удосконалено метод ресурсної черги у частині виокремлення процедури мінімізації витрат у межах відносно стабільних складових собівартості продукції, що мають найвищі ранги черговості свого покриття.

Практична значимість. Наукові результати можуть бути використані в діяльності машинобудівних підприємств для ефективного управління оборотними активами в умовах фінансово-економічної нестабільності.

Ключові слова: оборотні активи, управління відтворенням оборотних активів, операційний цикл, ресурсна черга, собівартість, дохід

\section{Управление воспроизводством оборотных активов машиностроительных предприятий Украины}

\section{Ю. В. Дубей}

Национальный технический университет „Днепровская политехника“, г. Днепр, Украина, e-mail: yuliya.dubey@ gmail.com

Цель. Определение особенностей управления воспроизведением оборотных активов машиностроительных предприятий и обоснование направлений повышения эффективности их использования.

Методика. В работе использованы следующие методы: канонический и дискриминантный анализ - при разработке концептуального подхода к управлению воспроизведением оборотных активов машиностроительного предприятия; группировки - при выделении составляющих себестоимости продукции машиностроительного предприятия; общего и особенного - при выявлении специфики деятельности предприятий машиностроительного комплекса по сравнению с другими промышленными предприятиями, а также при разработке научнопрактических положений, определяющих формирование ресурсной очереди, при условии, что доход покрывает (не покрывает) себестоимость продукции; ранжирование при установлении приоритетности покрытия расходов.

Результаты. Выявлена специфика формирования и использования оборотных активов машиностроительных предприятий и на этой основе предложен концептуальный подход к управлению их воспроизведением. Проанализирована сущность метода ресурсной очереди и разработаны предложения по его адаптации к специфике деятельности предприятий тяжелого машиностроения. На примере производства вагонов на ОАО „Днепровагонмаш“ применен методический подход ресурсной очереди и предложен алгоритм очередности возмещения ресурсов при различных условиях соотношения себестоимости продукции и выручки от ее реализации.

Научная новизна. Усовершенствован метод ресурсной очереди в части выделения процедуры минимизации расходов в пределах относительно стабильных составляющих себестоимости продукции, которые имеют высокие ранги очередности своего покрытия.

Практическая значимость. Научные результаты могут быть использованы в деятельности машиностроительных предприятий для эффективного управления оборотными активами в условиях финансово-экономической нестабильности.

Ключевые слова: оборотные активы, управление воспроизведением оборотных активов, операционный цикл, ресурсная очередь, себестоимость, доход

Рекомендовано до публікації докт. екон. наук В. Я. Швецем. Дата надходження рукопису 07.08.18. 